\title{
A Study on Classroom Spatial Performance: Its Impacts on Students' Satisfaction and Study Achievement
}

\author{
Sri Astuti Indriyati, Ph.D \\ Universitas Persada Indonesia Y.A.I \\ Indriyati@yai.ac.id / sriastutiindriyati@yahoo.com
}

Doi:10.5901/mjss.2015.v6n4s3p642

\begin{abstract}
The objective of this paper was to find out whether classroom spatial performance impact the satisfactorily of the students and their study achievement, using the case study of higher-degree students in department of architecture in one of Private University, located in inner-city of Jakarta (Indonesia). This study employed assesments on both physical and psychological conditions of classrooms and further have seen how these two classified conditions impact on satisfaction of students in using it. It was also to see how those conditions impact on students' academic achievement other than satisfaction level. Using the Post Occupancy Evaluation, the research employed a process of interviews with the students as a classrooms' users and observation to the spatial conditions as well. The study found out that each and both Physical and Psychological Conditions of classrooms simultanuosly have an influenced to students' satisfaction as well as to their academic achievements.
\end{abstract}

Keywords: classroom, spatial performance, satisfaction, academic achievement, study achievement

\section{Introduction}

All countries now compete to produce qualified human resource who was expected those from educated ones. Highlyeducated people was resulted from those studied in the college or university. Their academic achievement becomes very crucial for those to gain best future in their career. For that, it came up to the questions what would be the factors impacting their achievement as a "start-up kit" for being successful in the future? Is spatial performance of the place they are using when their studying time at university brought an impact toward their achivement? Should people be satisfied with the space they use to study when they intended to reach best academic achievements?

The objective of this research is to find out how a spatial performance in the case of classroom within the university will relate and impact to the satisfaction and study achievement of the students. By having the results of this study, the Architects and Designers as well as the Owners of the university in the future will understand how spatial design for the core space e.q. classroom in the university will require more attention.

From the objective mentioned above, it is therefore this research was conducted. It was an attempt to find out whether spatial performance - consists of Physical and Psychological Conditions of classrooms have an influenced toward students' satisfaction as well as their academic achievements, particularly in the case of students from Architecture Department in one Private University located in inner-city of Jakarta.

\section{Literature Review}

One of factors which may impact the students' academic achievement is the quality of space they use for studying. The quality of space means that all requirements need to be met. According to Indriyati's book (2009), Environmental design is influenced by the way people try to meet the needs based on understanding of the criteria for a well-built environment, those include to meet the needs of users in physical terms such as functional design and floorspace requirements. Other than that, a well-designed of built-environment also requires the needs to understand user perceptions of psychological, perceptual and social conditions. All physical, psychological and techincal problems are affecting each other. Specified example was mentioned by Komarudin (1997), that physical and technical problems also affect psychological feelings, like limited floorspace creates poor circulation and stuffiness in the rooms and having difficulities in making spatial arrangements. Psychological aspects are crucial and required to be assesed. Goodrich (1982) points out that many design solutions might unintentionally reduce perceived privacy, particularly in the case of noises and movements outside which are sudden and unanticipated and making them more distracting. 
One it may relevant to this research as an innitial idea seen in the previous research results conducted by Indriyati (2015), it is said that spatial performance consists of physical and psychological performance influences work productivity. This research was to prove whether it was the logic similaralities in which work productivity is equal to Study Achievement of the students and the Spatial Performance is analogic to the Classroom as a student's space to use for learning activity. This innitial assumption was then strenghtened by the literatures which further found out supporting specifically on this related case.

Previous research done by Jullian R., Betts, Andrew C., Zau., Lorien., O. Rice (2003) has found that the school and classroom were the most influenced factor to the student achievements. It is also found that class size appears to matters more in lower grades than in upper grades, whereas teacher qualifications such as experience, level of education and subject area knowledge appear to matter more in the upper class. This finding is indirectly saying that class size which further related to the class floorspace and it was used for physical spatial assessment is to be an issue influencing student achievement, especially for reading achievement. This become one fact that research need to be conducted to prove in detail what would be occured in University level? Whether or not the student achievement is influenced by the spatial classroom performance?

Other research was reported by John K., Rugutt and Caroline C., Chemosit (2005) stated that the Campus Technology including internet access, quality of instruction and overall college experience and student-faculty interaction significantly impact academic achievement. Kwesiga (2002) approved that performance of the students is also influenced by the school in which they studied but they also said that number of facilities in school offers and ussualy determine the quality of school which in turn affect the performance and accomplishment of its students. In this case, physical spatial qualities including campus technology supports are highly demanding and need to consider.

One commentary given by Director of Public Schools (David, 2010) has mentioned that learning can not take place in a chaotic environment and research has also mentioned that learning effectively takes place when it is presented in a fun and engaging manner or nice place for studying. Factors that affect student achievement was also clarified by Miyem Supriyati (2013) - one is enviromental conditions. Selecting a good learning environment is to be primary considered. In the case of Philippine Basic Education, it was found the fact that having sufficient space for the classrooms are required to support the academic achivement of students (Angel C. de Dios, 2012). It means that classroom physical comfort and sufficiency become one to be concerned.

Walberg's theory on academic achievement posits that psychological of individual's characteristics (students) and their intermediate environments influence educational results (cognitive, behavioral and attitudinal) (Reynolds, A. R., \& Walberg, H. J. (1992). Further, Walberg's research has 9 (nine) key variables which told us its influences toward the student educational results, such as student ability/prior achievement, motivation, development level/age, quantity of instruction, quality of instruction, classroom climate, home environment, peer group and exposure to mass media outside of school (Walberg, Fraser \& Welch, 1986). Research on Learning Environments by Astin (1993) has taken a reference of Fraser, Walberg, Welch and Hattie (1987) \& Fullarton (2002) express that psychological characteristics of classroom learning environments - one overall student engagement in learning - demonstrate incremental validity in estimating student outcomes. Theory given by Holland (1997) indicated that student's experience at school and saying that a student achivement is to include a function of personality type and the academic enviroment. These all researchs' finding support the argument that classroom climate is one key variable to be consider influencing student academic achievement.

Having reviewed literatures reporting prior research results, it is clear that student achievement are influenced by spatial performance, both physical and psychological performances. Indicators may be used to do spatial assesment for physical performance in the case of this research were: availability of floor space; flexibility of the room for its functions; the shape of room for usage. Similarly, the indicators used to assess the spatial psychological performance were glare; heating condition; freshness/stuffiness of the room air; room's air circulation system; visual privacy of room; and conversational privacy of room (Indriyati, 2013).

\section{Research Methodology}

Methodology used for the research has met a standard to conclude a well-represented research. Post Occupancy Evaluation (POE) was employed, defined as a process of interviews with the students as a classrooms' users and observation to the spatial conditions as well. The reason to use POE due to the increasing needs of Architects and Designers to receive a feedbacks how users perceived toward its current typical university design - particularly for the classroom design. By using this POE, it was done to assess what the greatest and poor perceptions of users toward the space provided for them. 
The students sitting in higher semester were taken as respondents. It was selected one private University located in City Centre where the land value are very high and tendenciously to provide a very minimum physical building constructions. The issue of land constrain - providing rooms sufficiently - becomes one to be concerned if the result of study shows dissatisfactorily and ultimately pushing an impact to the student academic achievement. The data collected from the 40 students studying in Architecture Department with a classrooms' floorspace of $>10-20$ sqm; $>20-30$ sqm and $>30$ sqm. A simple random sampling was taken out for the survey. Sample size was determined using the table produced by Krejcie and D. W. Morgan (1970) in Sarantakos (1998). The 40 (forty) students out of 45 students who study in Architecture department were selected to be interviewed. Observation to classrooms, focusing in physical room's items of assesments were also conducted to confirm respondents' answers taken from the interview process. The 2 (two) variables of research models used in order to assess relationships between Physical Spatial Performance and Psychological Spatial Performance. They both were employed firstly to see its relationships. These 2 (two) variables were also each and both to be assesed for their impacts toward their satisfaction to the classrooms available for them and further to assess how its impacts on student academic achivement. Method of data processing with SPSS Software. Mixed Analysis Method was used. Correlations and Regression were used for analysis.

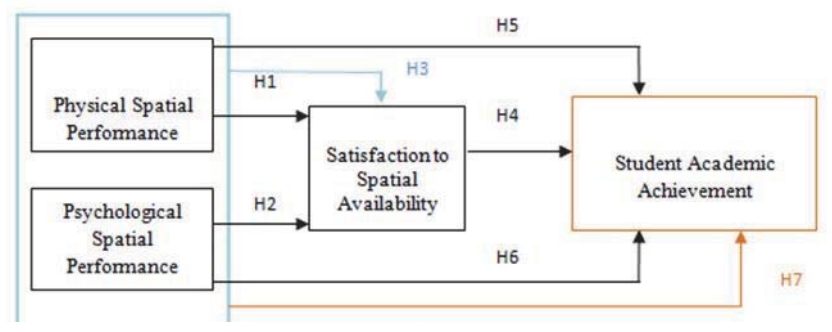

Figure 1. Research Scheme Models

\section{Analysis and Results}

\subsection{Respondent Characteristics}

Table 1 show characteristics of respondents. The majority of respondents were the students sitting in semester 5 \& semester 6 within the range of age $>21-27$ years old. The classrooms in Architecture Department are mostly occupied equaly male or female. That represents on the respondents as well while only little difference percentage showed between female and male students. Most of students participating in the research were taking the subjects and sitting in the 6th floor with the classrooms size between $>20-30$ sqm.

The respondent's majority characteristic have shown considerably appropriate or meeting its representativenes as those sitting in the appropriate semester in terms of length of study and also within the mature age, therefore they can provide a true facts for this assesment process. The students response were also mostly given by those occupying the middle classroom size (not the smallest classroom size).

Table 1. Respondents Highlighted Characteristics

\begin{tabular}{|lcc|}
\hline Characters & Item found in Majority & Frequencies (\%) \\
\hline Semester Seats & Semester $5-6$ & 37.5 \\
\hline Age & $>21-27$ years old & 52.5 \\
\hline Gender & Male & 52.5 \\
\hline Floor space $(\mathrm{sq} \mathrm{m})$ & $>20-30 \mathrm{sqm}$ & 52.5 \\
\hline Building Height $\left(1^{\text {st }}-8^{\text {th }}\right.$ floor $)$ & 6 th floor & 45.0 \\
\hline
\end{tabular}

\subsection{Results}

The findings reported below are significant for Architects and Designers as well as Institutional Managements to provide an appropriate design for the classrooms in the future and further to gain a better quality of university in general, its students and graduates as well as the university values. The statistical results as presented in Table 2 below. 
Table 2. Results of the Partial and Simultaneous Assessments

\begin{tabular}{|lcccc|}
\hline $\begin{array}{l}\text { Hypotheses } \\
\text { H1 Influenced/ R2 (\%) }\end{array}$ & R Linier Cooeficient & P Value & Statistical Conclusions \\
Students' Satisfaction to Spatial Availability & 36.7 & 0.605 & 0.006 & Significant \\
\hline $\begin{array}{l}\text { There is an impact of Psychological Spatial Performance } \\
\text { on Students' Satisfaction to Spatial Availability of the } \\
\text { students }\end{array}$ & 54.1 & 0.736 & 0.000 & Significant \\
\hline $\begin{array}{l}\text { There is an impact of both Physical and Psychological } \\
\text { H3 Performance on Students' Satisfaction to Spatial } \\
\text { Availability of the students }\end{array}$ & 65.2 & 0.807 & 0.000 & Significant \\
\hline H4 $\begin{array}{l}\text { There is an impact of Student's Satisfaction to Spatial } \\
\text { Availability on the Students' Academic Achievements }\end{array}$ & 33.0 & 0.575 & 0.000 & Significant \\
\hline H5 $\begin{array}{l}\text { There is an impact of Physical Spatial Performance on the } \\
\text { Students' Academic Achievements }\end{array}$ & 34.7 & 0.589 & 0.010 \\
\hline H6 $\begin{array}{l}\text { There is an impact of Psychological Spatial Performance } \\
\text { on the Students' Academic Achievements }\end{array}$ & 40.4 & 0.636 & Significant \\
\hline H7 $\begin{array}{l}\text { There is an impact of both Physical and Psychological } \\
\text { Performance on the Students' Academic Achievements }\end{array}$ & 50.8 & 0.713 & 0.019 \\
\hline
\end{tabular}

The results of study have found significant and useful for Architects and Designers as well as Institutional Managements to provide an appropriate classroom design in the future. A better classroom design will lead to increase the quality of students graduating from the university and its university reputation and credibility.

Research has clearly found that: (1) The Spatial Performance - both Physical and Psychological Performance - has an influenced toward the Students' Satisfaction to their classrooms and its facilities provided within their classrooms; (2) The Physical and Psychological Spatial Performance indicate significantly influencing the students' satisfactions (0.006 for physical performance $\& 0.000$ for psychological performance), It is to confirm that people absolutely needs to have a sufficient quality of both physical setting for them to study effectively and psychologcally acceptable; (3) The two spatial assesments - physical and psychological spatial performance - have shown its positive impact to student academic achievement (0.000); (4) The Satisfaction of the students toward their quality of classrooms available for them has also highly-influenced by both Physical and Psychological Spatial Performance which is reaching the $36.7 \%$ for the Phsyical and $54.1 \%$ for the Psychological Space Performance and reaching $65.2 \%$ for both Physical and Psychological Performance. This result has indicated that students' satisfaction of classrooms are strongly influenced by Psychological aspects compared to physical ones. It is to conclude that people like to have their classrooms psychologically accepted more rather than physical one. Students are happy as long as psychologically conditions are accepted for them, such as the requirements on controlling the glare, heating conditions, freshness and air circulations and humidity within the rooms; (5) The Student Academic Achievement are significantly influenced by the satisfactions of students toward their classrooms (33.0\% of respondents). The Student Academic Achievement are high-influenced by the Spatial Performance - each Physical or Psychological performance and both Physical and Psychological performances. The Psychological performance alone are taking more influenced compared with the Physical Spatial Performance $(40.4 \%$ compared to $34.7 \%)$. The psychological aspects found significant is glare effects $(0.043)$.

\section{Conclusions}

This paper reported the results of spatial assessment obtained from those students using their classrooms in the inner city university. This result is specific and can not be assumed representing of those students studying in other campus which is located not in the city centre with its land constrain not an issue.

This research has justified that Spatial Performance consists of Physical and Psychological Performance influence the student satisfaction toward their classrooms, including this Information and Communication Technology (ICT) in the classrooms. Psychological Performance one has done and shown strongly influences the student satisfaction of classrooms. It indicates that students tend to have a well-psychological conditioned room and less concerned to what physical aspects. Satisfaction of the students to their quality of classrooms and the ICT provided has also higly-influenced by both Physical and Psychological Spatial Performance. Student Academic Achievement was also found influenced significantly by satisfaction perceived by the students. Similar to this, the spatial performance both physical and psychological performance have influenced to the student academic outcomes. However, it was indicated that spatial performance underlining the Psychological aspects tend to be dominantly expected by the students in relations to their academic achievement. This students' academic achievements are strongly influenced by Psychological aspects 
compared to physical ones. Therefore, students tend to have their classrooms psychologically acceptable rather than physical ones.

This research has confirmed the previous other researches results which was saying that in general classroom physical comfort is important and classroom climate (pscyhological aspects) is a key variables for student academic achievement. However, this research was more extensive compared to prior ones since the results has proven in detail that spatial performance are seen from both physical and psychological aspects, where as others only combined all aspects. This research has justified that both physical and psychological performance impact on students' satisfaction toward their classroom and student academic achievement. It even clarifies in detail that psychological aspects of classrooms' performance is more likely to be concerned by the students for their satisfaction and study achievement.

It is suggested that future research needs to carry out in order to oversee another angle, such as the classrooms performance in different location which land constraint is not an issue. The selection of respondents taken from different major of studies will also presumably providing different results, due to Architecture students are presumably more tendencious to assess any space for their activities. Their values toward their space including classrooms would be more sensible than those have different education backgrounds. It was good in one side to provide more genuine and accurate assessment results, but not to produce a general values of classroom design. It may be found that students with different study background will less concerned on quality of space or classroom and its surrounds. Therefore, the optimum values of classroom spatial requirement will further possible to be gained. The future predicted hypotheses could be assumed that different student backgrounds will have different assesments of space. In addition, different campus locations are more likely different values to be perceived by the students as well. Moreover, it is also highly possibility that there would be another findings that may result the difference between the value of space used for the biggest classrooms size and the medium and small sizes.

\section{References}

Astin, A. W. (1993). What matters in college? Four critical years revisited. San Fransisco Jossey-Bass.

Angel, C., de Dios, (2012), Factors that influence Student Achievement. Philippine Basic Education. (Online) Available: http://philbasic education.blogspot.com/2012/12/factors-that-influence-student.html (December 20, 2012).

David, S., Glennon (2010). Guest Commentary: 4 Factors have greatest impact on students achievement.

Fraser, B. J., Walberg, H. J., Welch, W.W., \& Hattie, I.A. (1987). Syntheses of educational productivity research. International Journal of Educational Research, 11, 145-252.

Fullarton, S. (2002). Student engagement with school: Individual and school-level influences longitudinal surveys of Australian youth. Research Report No. LSAY-27. (ERIC Document Reproduction. Journal of Educational Research \& Policy Studies 86 Service No. ED 470798$)$.

Goodrich, R. (1982). The Perceived Office: The Office Environment as Experienced by its Users. In Wineman, J. (1986). Behavioral Issues in Office Design (pp.109-133). New York: Van Nostrand Reinhold.

Holland, J. L. (1997). Making Vocational Choices: A Theory of Vocational Personalities and Work Environments (3rd ed.). Odesa, FL: Psychological Assesment Resources.

Indriyati, S.A. (2009). Low-Cost Housing in Jakarta: Toward a More Humane Architecture, Bandung: Pustaka Sutera.

Indriyati, S.A. (2013). Space and Behavior: Study on Spatial Use of the Low-Cost Housing and its Residents. International Journal of Development and Sustainability, 2, 3, pp.1982-1996.

Indriyati, S.A. (2015). Spatial Performance Impact on the Employees' Productivity and Satisfaction: Implication on Coping Strategies to the Working Space. International Journal Research on Humanities and Social Sciences, 5, 4, pp. 119-125.

Jullian R., Betts, Andrew C., Zau., Lorien., O. Rice (2003). Determinants of Student Achievement: New Evidence from San Diego. San Fransisco, CA: Public Policy Institute of California.

Komarudin. (1997). Menelusuri Pembangunan Perumahan dan Permukiman. Jakarta: P.T. Rakasindo, Yayasan Realestat Indonesia.

Krejcie and D.W. Morgan. (1970) Determining Sample Size for Research Activities. In Educational and Psychological Measurement, 30, pp. 607-610.

K., Rugutt and Caroline C., Chemosit (2005). A Study of Factors that influence College Academic Achievement: A Structural Equation Modeling Approach. Journal of Educational Research \& Policy Studies, 5, 1, pp. 66-90

Kwesiga, C.J., (2002). Women's access to higher education in Africa. Uganda's experience. Kampala: Fountain publishers Ltd.

Miyem Supriyati (2013). Factors that affect student achivement. Life is Beautiful.

(Online) Available: http://smallbusinesswithbestmarketing.blogspot.com/2013/03/factors-that-affect-student-achievement.html (March 10, 2013).

Reynolds, A. R., \& Walberg, H. J. (1992). A process model of mathematics achievement and attitude. Journal of Research in Mathematics, 23, 306-328.

Sarantakos, S. (1998). Social Research, Australia, Melbourne: MacMillan Publishers Australia PTY LTD.

Walberg, H.J., Fraser, B. J., \& Welch, W. W. (1986). A test of a model of educational productivity among senior high school students. Journal of Educational Research, 79, 133-139. 